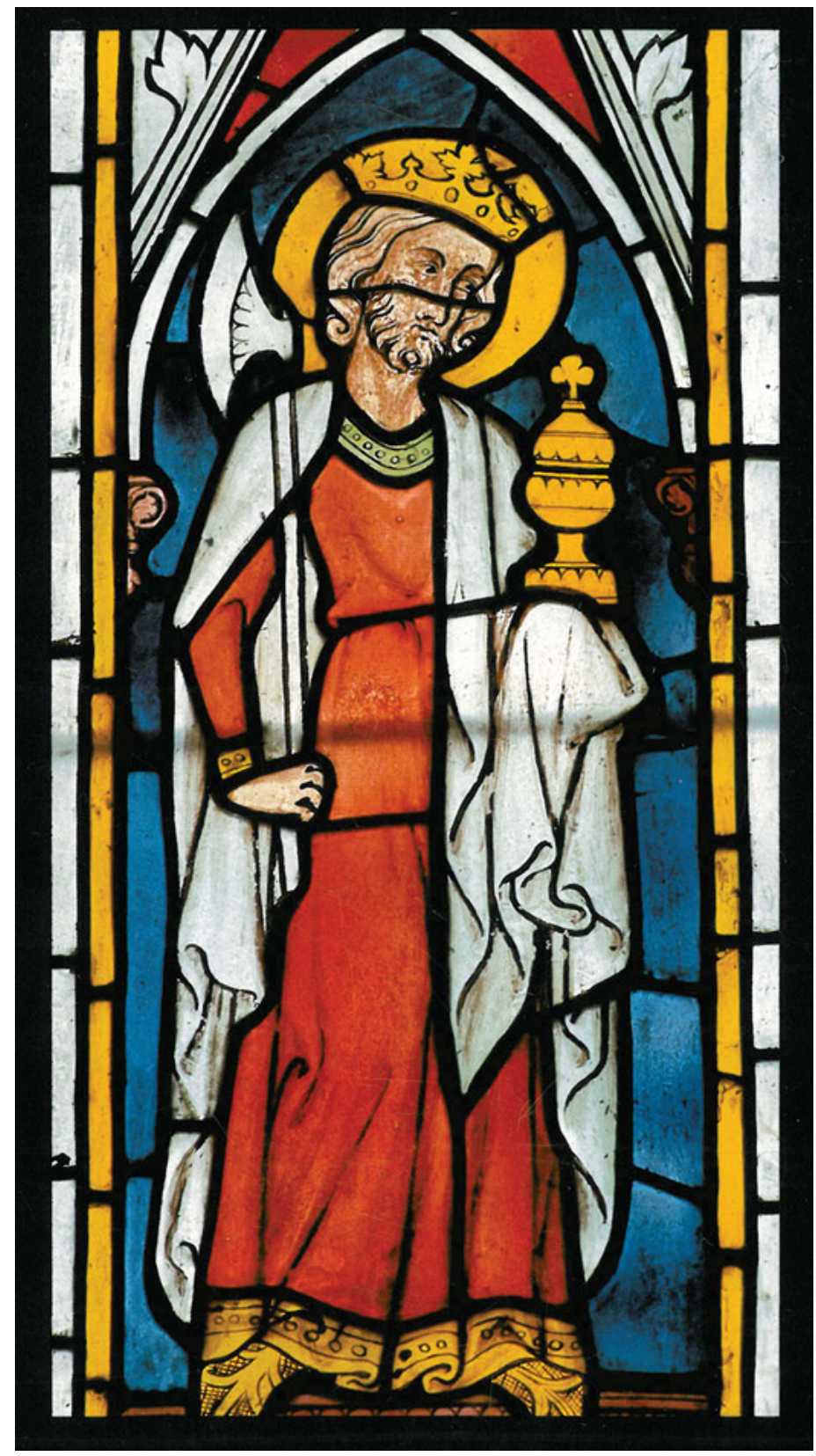

Fig. 14.1: St Olav, king and matyr. Stained glass window from Lye Church, Gotland, c.1325. The holy king holds an axe - his attribute - in his right hand and a lidded chalice in his left.

Ә Open Access. (๑) 2021 Øystein Ekroll, published by De Gruyter. (c) BY-NC-ND This work is licensed under the Creative Commons Attribution-NonCommercial-NoDerivatives 4.0 International License.

https://doi.org/10.1515/9783110639438-015 


\section{Øystein Ekroll}

Chapter 14

St Olav, Nidaros, and Jerusalem

Norway became incorporated into the Western Christendom during the eleventh century, a process which was completed with the establishment of a Norwegian church province in 1153. This history is inextricably linked with the history of St Olav, the most important medieval Scandinavian saint. A recurring theme in his cult is his Christ-like persona, which was also expressed in the architecture of Nidaros Cathedral, his final resting-place. During the twelfth century, cultural impulses were transmitted from Jerusalem to Nidaros, leaving marks on the town, the cathedral, and his cult. This chapter explores how and why this happened.

In the 1070s, during the early reign of King Olav III (1067-1093), the chronicler Adam of Bremen (d. c.1085) wrote his large history of the archbishops of Bremen, and in his work he included some information about the Nordic lands, which until 1104 formed a part of the archbishopric of Hamburg/Bremen. According to Adam, the largest town in Norway was Trondheim, which was embellished with several churches and is visited by many. The body of the blessed king and martyr Olav rested there, and at his grave God worked many miracles, and people who sought help from the holy man come there from afar. ${ }^{1}$ His martyr feast is celebrated on 29 July, and his memory is honoured among the peoples around the Northern ocean: Norwegians, Swedes, Goths, Danes, and Slavs. ${ }^{2}$

Concerning the circumstances of Olav's martyrdom, Adam had conflicting information. He recorded that some say that Olav was killed by sorcerers, who were numerous in Norway, others report that he died in battle, and yet others maintain that he was assassinated by agents of King Knud the Great (d. 1035). Adam himself found the latter theory most probable. ${ }^{3}$ Adam never visited Norway, but he travelled to Denmark and received much information from King Sven Estridsen (1047-1076).

Perhaps unknown to Adam, the cult of St Olav was already established in England. The oldest liturgical sources for the cult of St Olav are English, consisting of an office and litanies preserved in the Leofric Collectar from the 1050s-1060s,

1 Adam of Bremen, The History of the Archbishops of Hamburg-Bremen, trans. Francis Joseph Tschan, New York: Columbia University Press, 1959.

2 Adam of Bremen, The History of the Archbishops:, ii, ch. 61.

3 Adam of Bremen, The History of the Archbishops:, ii, ch. 57, 61.

Øystein Ekroll, archaeologist and researcher at the Restoration Workshop of Nidaros Cathedral, Trondheim, Norway 
named after Bishop Leofric of Exeter (c.1016-1072) who had close contact with the highest circles in Anglo-Saxon England. There seems to be general agreement that this office was created by Grimkjell, the missionary bishop of St Olav, who canonized the king. Grimkjell is probably identical with Grimketel/ Grimcytel/ Grimkillus who was bishop of Selsey in Sussex 1038-1047. ${ }^{4}$

In the 1050s, Bishop Leofric attested that Countess Gyða gave a donation for a church in Exeter, built for the benefit of the souls of her husband, Earl Godwin, and herself. This church was to be dedicated to Sancti Olavi regis et martiris. Likewise, Earl Siward of Northumbria built a church in York dedicated to St Olav, in which the earl was buried in 1055, and King Edward the Confessor (1003-1066) made donations to build a church dedicated to St Olav somewhere in England. Before 1100, perhaps even before 1066, there were at least three churches dedicated to St Olav in the city of London, and other churches dedicated to him in Southwark, Exeter, Chichester, Norwich, and Chester. In 1074, we hear about relics de uestimento sancti Olaui regis (of the vestments of St Olav the king) in the Christchurch in Dublin, and a St Olav church was built in the harbour area. ${ }^{5}$

Considering the close family contacts between the Scandinavian and Russian royal dynasties during the eleventh and twelfth centuries, it is not surprising to find an early St Olav church in Novgorod and reports of miracles taking place there. ${ }^{6} \mathrm{By}$ the 1090s, a church was also built in honour of St Olav in Constantinople as a result of the saint aiding the Byzantines at a critical moment during a large battle. ${ }^{7}$ St Olav was canonized before the Great Schism in 1054, and he was thus one of the last saints that was recognized in both the Orthodox and Roman Church.

Within a few decades of his death, the cult of St Olav had become international and was established from the British Isles in the west to Constantinople in the east, at least among Scandinavian merchants and mercenaries and the local elites of Scandinavian descent. The rapid spread of his cult, fuelled by the many miracles attributed to him, is remarkable in an eleventh-century context. The Norwegian church was still in its infancy and possessed few resources to promote the cult. The Norwegian kings had a stronger power base, but until 1066 were constantly engaged in conflicts and wars with the surrounding kingdoms.

4 NBL, s.v. Grimkjell.

5 Øystein Ekroll, “Olavsrelikvier - myter og fakta," in Helgenkongen St. Olav i kunsten, ed. Øystein Ekroll (Trondheim: Museumsforlaget, 2016), especially 269.

6 The church is mentioned in the Passio Olavi, and was situated in the merchants' quarter by the River Volkhov.

7 This miracle is first described in the the poem Geisli from c.1153 (see e.g. Einarr Skúlason's Geisli: A Critical Edition, ed. M. Chase, Toronto: University of Toronto Press, 2005), and took place during the reign of Emperor Alexios I Komnenos, probably in 1091. It is also mentioned in the Passio Olavi. Lidingssoga og undergjerningane åt den heilage Olav, trans. Eiliv Skard, Oslo: Det norske samlaget, 1930. 
St Olav also placed the small and hitherto insignificant town of Nidaros/ Trondheim, situated on the northern edge of the Christian world, on the European map of pilgrimage sites. According to Adam of Bremen, by 1070 people from several countries ventured to Trondheim to pray for help at the saint's shrine. His cult made Trondheim into an international town early on, and the many pilgrims who came brought influences and impulses to Trondheim which otherwise would not have been transfered there.

Trondheim's distant position on the very edge of the known world, bordering on wild and icy regions filled with demons and evil creatures also turned it into a mythical place, situated within reach only for the dedicated few who were prepared to brave many dangers. ${ }^{8}$ The place shared this mythical dimension with Santiago de Compostela and especially with Jerusalem, which was also situated beyond the ocean but without the same dangers attached. However, one hundred years later Trondheim was firmly established as a metropolitan seat and its urban structure was consciously developed to reflect important aspects of contemporary Jerusalem. Eventually, the cult of St Olav also became modeled on how Christ was depicted and venerated. The question is then, how did this come to happen in the course of a century?

\section{The Life and Death of King Olav Haraldson, 995-1030}

King Olav Haraldsson belonged to the royal line which had ruled Norway since around 900. He was the great-grandson of King Harald Fairhair (d. 932), who first united Norway into one kingdom. ${ }^{9}$ Olav was born in 995, and after his early years spent as a Viking and a mercenary from the age of twelve, mainly in the British Isles, he was converted to Christianity and baptized in Rouen in Normandy in 1014. By then, he had collected a considerable treasure, and in 1015 his window of opportunity came to conquer the throne of Norway. The two earls, Eirik and Svein, sons of Earl Haakon of Lade (c.935-c.995), governed Norway as vassals of the Danish kings, first Svein Forkbeard and then his son Knud the Great. When King Knud called Eirik, the most able of the brothers, to England in 1015, Olav

\footnotetext{
8 On the conception of the monstrous arctic regions, see Kristin B. Aavitsland's introduction to this book, Chapter 1, 21-4.

9 The following story of St Olav's life is mainly taken from the literary descriptions in the various sagas written down in the thirteenth century, mainly Snorri Sturluson's Heimskringla written c.1230 (Snorri Sturluson, Heimskringla, 3 vols, trans. Alison Finlay and Anthony Faulkes, London: Viking Society for Northern Research, University College London, 2016, vol. 2, Óláfs saga helga). The main facts can be verified through contemporary sources, but the details must be regarded as a mixture of popular legends and literary inventions.
} 
sailed to Norway with two ships, and through generous gifts he managed to gather wide support for his claim to the throne. In March 1016, Olav beat the forces of Earl Svein in the sea battle at Nesjar in Vestfold. ${ }^{10}$ Svein fled to Sweden and died shortly after, and Olav was proclaimed king of Norway at the Eyrathing in Nidaros. ${ }^{11}$

With the zeal of the newly converted, Olav set out to eradicate the last remnants of paganism in his kingdom, which was often done by force with sword in hand, leaving a bloody trail. In this process, the local magnates lost much of their power, and a disgruntled number of them made a secret alliance with King Knud the Great of Denmark and England, who strived to bring Norway back into his North Sea empire. The magnates accepted Knud as their over-lord, and in his turn he promised to give them a large degree of self-rule. In 1028, this alliance forced King Olav into exile, and he fled to Russia, to the court of Grand Prince Yaroslav of Kiev and Novgorod (978-1054) and to Yaroslav's Swedish-born wife, Ingegjerd, the half-sister of Olav's wife, Astrid.

King Knud's promise to the Norwegian magnates was not fulfilled, however, as he installed his oldest son Svein (c.1020-1036) and his English mother Ælfgifu (Alfiva) of Northampton as rulers of Norway, residing in Nidaros. They soon managed to make themselves more unpopular than Olav had been, and according to the sagas, the Norwegian magnates soon regretted their deal with Knud.

In an effort to regain his kingdom, King Olav left Russia in 1029 with a small army. His five year old son Magnus was left in Russia in the care of his father's inlaws. Olav marched through Central Sweden and Jemtland and crossed into Norway through Verdal, but his enemies met him with a large army at Stiklestad in the lower part of the valley. Olav was killed in the Battle of Stiklestad on 29 July 1030, as was most of his army. His half-brother and later king Harald was wounded, but escaped and eventually found his way back to Russia and then to Constantinople where he joined the Imperial Guard (the Varangians).

According to Snorri Sturluson's Heimskringla from c.1230, king Olav's body was hidden by a local farmer in a shed or barn, washed and placed in a coffin. The farmer and some trusted friends hid the coffin in a boat and brought it by night to a shed by the river in Nidaros. The town was in the hands of the king's enemies, however, and none of the king's friends dared to take charge of the coffin. The men therefore carried the coffin back into the boat, rowed further upriver out of sight from the town, and buried the coffin in a sandbank by the river, and then obliterated all traces of the burial before returning home. This secret and unceremonious

10 In Chapter 4, Bjørn Bandlien discuss the battle of Nesjar and its ideological reception and symbolic interpretations in skaldic poetry, 59-85.

11 The Eyraping was an assembly that convened solely to proclaim a new king. The assembly met on the gravelly flats (ON eyrr) where the River Nid meets the Trondheim Fjord, hence its name. 
burial by night would normally spell the end of the story of a failed king who had gambled and lost everything.

Shortly after, however, rumours started to swirl about miracles taking place in connection with the king's death, heralding that he was a holy man. Thorir Hundr, one of the men who killed the king, was instantly cured of a hand wound when he touched the dead king's body. ${ }^{12}$ Simultanously, an old and blind beggar got some of the blood-mixed water from the washing of the king's body into his eyes, and instantly his eyesight was restored. ${ }^{13}$ According to the Saga of King Magnus the Good, Thorir soon left Norway on a pilgrimage to Jerusalem to atone his deed, and was believed never to have returned home. ${ }^{14}$ This is the first recorded connection between the death of Olav and Jerusalem, and Thorir is the first recorded Norwegian pilgrim.

By the summer of 1031, the rumours had grown so strong that the public sentiment turned against the Danish rulers. King Olav's bishop Grimkjell, an Anglo-Saxon who had followed Olav from England in 1015, returned to Nidaros and received King Svein's permission to open the grave. The farmers from Stiklestad were called to Nidaros and pointed out the site of the burial. The coffin had then moved almost to the surface. It was uncovered and reburied outside St Clement's Church, presumably with Christian burial rites.

Soon, however, the coffin re-emerged on the surface, a clear sign that the king did not wish to stay underground. On the 3 of August 1031, one year and five days after Olav's death, the coffin was opened by Bishop Grimkjell in the presence of King Svein and a large crowd. The king's face was uncovered and they saw that it was as fresh as the day he died and his hair and nails had grown during the preceding year. The bishop then lit a fire which he blessed and sprinkled with incense. He cut off some of the king's hair and placed it in the fire, and the hair emerged unharmed.

Despite the protest of Ælfgifu, who demanded a second test without blessing the fire, this was taken as decisive evidence of the king's holiness, and with the approval of King Svein and the assembled populace the bishop then declared that Olav was a saint. ${ }^{15}$ The coffin was placed above or behind the altar in St Clement's Church, covered in costly textile and a canopy of cloth hung above it.

12 Snorri Sturlusson, Heimskringla, vol. 3, Magnúss saga ins goða, ch. 11.

13 Snorri Sturlusson, Heimskringla, vol. 2, Óláfs saga helga, ch. 236.

14 Snorri Sturlusson, Heimskringla, vol. 3, Magnúss saga ins goða, ch. 11.

15 At this time, this procedure sufficed to declare that someone was a saint. Before c.1200, the pope and the curia had no final say in the matter of declaring saints. 


\section{The Early Cult of St Olav in the Churches at Nidaros}

During a period of sixty years, the shrine of St Olav was kept in no less than four different churches in Nidaros. This attests to the rapid expansion of the town as well as the cult and importance of the saint. In the following, we will trace the movements of St Olav's shrine through the first century of his cult.

\section{St Clement's Church}

When the saint's coffin was placed in St Clement's Church, it immediately became a place of pilgrimage, as two scaldic poems from the 1030s indicate. The first, Glælognskvida by Torarin Lovtunga, begins with a description of the saint's incorrupt body with his hair and nails growing. This was the greatest miracle of all, a direct sign of God's mercy. Then we hear how bells rang and candles were lit by themselves without help by human hands, and how the blind and crippled walked away seeing and healthy after praying at Olav's shrine. The second poem, Erfidråpa by Sigvat Thordsson, is addressed to King Svein and advises him to pray to St Olav and accept his holiness if he wants keep his power. ${ }^{16}$

But this good advice was in vain: By 1035, the public sentiment had turned so much against King Svein and his dominant mother Ælfgifu that they left the country. A group of Norwegian magnates went to Russia and brought the young Magnus Olavsson back to Norway, and he was acclaimed as king of Norway the same year. Fortunately for him, King Knud died in November 1035, creating a power vacuum in his Anglo-Danish empire. King Magnus was therefore able to reign in Norway until his death in 1047, and from 1042 he was also king of Denmark after the death of King Knud III (Hardeknud), the last son of King Knud the Great. From 1046, King Magnus shared the throne with his half-uncle Harald the Hardruler (d. 1066), who returned from Constantinople with a great treasure that he split with Magnus.

King Magnus died in Denmark, and his body was brought all the way to Nidaros and buried in St Clement's Church, thus establishing the first royal dynastic burial church in Norway. ${ }^{17}$

16 Else Mundal and Lars Boje Mortensen, "Erkebispesetet i Nidaros - arnestad og verksted for olavslitteraturen,” in Ecclesia Nidrosiensis 1153-1537. Søkelys på Nidaroskirkens og Nidarosprovinsens historie, ed. Steinar Imsen (Trondheim: Tapir akademisk forlag, 2003), 354-7.

17 Snorri Sturlusson, Heimskringla, vol. 3, Haralds saga Sigurðarsonar, ch. 30. 


\section{St Olav's Church}

According to Heimskringla, King Magnus began to build a new royal residence in Nidaros with a stone hall and a stone church dedicated to his saintly father, but he died before either were completed. These were the first known stone buildings in Norway. The church was placed on the site of the shed where Olav's coffin lay hidden during the night after his death. King Harald the Hardruler completed both buildings, but converted the hall into a church dedicated to St Gregory. ${ }^{18}$ The coffin of St Olav, which by now was covered with silver and gold was transferred to St Olav's Church when it was completed, probably c.1050.

\section{St Mary's Church}

This residence was not used by the king for long, if at all. King Harald established a new royal residence some hundred meters further south along the river and built a stone church there dedicated to St Mary. When it was completed, the shrine of St Olav was transferred to this church. This took place before King Harald's death in the Battle at Stamford Bridge outside York in 1066. The year after the battle, King Harald's body was brought across the North Sea and buried in this church. Harald probably intended St Mary's to become a royal burial church with the shrine of his holy half-brother as its center, but this was not to be.

\section{The Holy Trinity Church (Christchurch)}

Harald's son King Olav III the Peaceful (r. 1067-1093) inherited the throne, and he built a large new stone church in the royal residence, close to St Mary's Church, which his father had erected. It was dedicated to the Holy Trinity but usually called the Christchurch, and it became the predecessor of the present-day Nidaros Cathedral. According to the saga, its altar was placed on the site of St Olav's grave from 1030 to $1031 .^{19}$ The tradition of the high altar standing above St Olav's grave is at best a pious fraud [pia fraus] which was not uncommon in the Middle Ages. When the ground below the altar was investigated in 1872, two medieval altar foundations

18 Snorri Sturlusson, Heimskringla, vol. 3, Haralds saga Sigurðarsonar, ch. 38.

19 Snorri Sturlusson, Heimskringla, vol. 2, Óláfs saga helga, ch. 245. 
were found, resting on three large, parallel slabs. These were lifted with great excitement, but below them was no trace of a grave, only a thick layer of clay. ${ }^{20}$

The cathedral stands on the highest point of the Nidarnes peninsula, and archeological excavations next to it in 1995 and 2005 uncovered the remains of several large wooden buildings here dating to the tenth and eleventh century. This was not a lonely and desolate place in 1030, but the center of a manor or large farm. It is possible then, that the real grave site was located on the sandbanks 200-300m further south by the river which was out of view, but a large stone church could not be built there. The whole location was thus transferred to the most prominent building site in the area, which formed the western part of the extensive royal residence.

When the Christchurch was completed, some time before King Olav III died in 1093, the shrine of St Olav was transferred to this church from St Mary's, and placed above the altar. The remains of his son, King Magnus Olavsson, were also transferred to this church. ${ }^{21}$ King Olav III died in the south-eastern part of Norway, but his body was brought all the way to Nidaros and buried in the Christchurch, as were almost all Norwegian kings during the next hundred years.

The foundation was thus laid for the Christchurch to become a dynastic royal mausoleum, which without doubt was the intention of King Olav III. He had chosen not to expand St Mary's, his father's church, but rather to build the larger Christchurch next to it, justifying this move by claiming that the royal saint had now returned to his original grave site. The saint's grave and shrine formed the nucleus of almost all royal burials in Norway during the twelfth century, until the tradition was discontinued by King Sverre and his descendants who chose to be buried in Bergen.

The importance of returning the saint to his presumed grave site is an interesting feature. In the case of older royal saints, e.g. St Edmund and St Oswald, their original burial sites did not attract the same importance in their cult as the churches where their relics finally came to rest. In the case of the two other Nordic royal saints St Knud and St Erik, their graves also did not attract the same importance. Their relics were kept in churches built close by, but not above, their original burial sites. Opposed to the Christchurch with St Olav's shrine, the churches of St Knud and St Erik did not attract the burials of their medieval descendants - a feature demonstrating the weaker position they retained in Denmark and Sweden respectively. Instead, the Danish royal mausoleum was formed around the grave of a third royal saint: Duke Knud Lavard, the

20 Otto Krefting, "Supplement til en i 1865 i Throndhjems Domkirke foretagen Undersøgelse," in Foreningen til norske Fortidsmindesmærkers Bevaring Aarsberetning for 1872 (Kristiania: Carl C. Werners \& Comp's Bogtrykkeri, 1873).

21 King Magnus was reburied outside the south wall of the chancel, but when the chancel was replaced by the octagon $c .1200$ the grave site was incorporated into the new building, situated under the south ambulatory. See Øystein Ekroll, "Magnus 1. Olavsson kaldet Magnus den Gode," in Danske Kongegrave, ed. Karin Kryger (Copenhagen: Museum Tusculanum Forlag, 2014), 157-67. 
son of King Erik the Good, who was murdered in 1131 and buried in Ringsted Abbey Church on Zealand. His son King Valdemar (r. 1154-1182), who was not yet born when his father was killed, managed to have his father canonized by the pope in 1170 after Valdemar emerged victorious from a bloody civil war. Ringsted Church was rebuilt and rededicated for this occasion, and as a part of the celebrations Valdemar's seven year old son, the later King Knud VI (r. 1182-1202), was anointed and crowned. This was the first Danish coronation, which helped to establish the church at Ringsted as the dynastic burial and coronation church of Denmark, with the shrine of the holy ancestor as the focal point. Until 1319, most Danish kings were buried in this church in front of Knud's shrine, which became the Danish parallel to the Christchurch in Nidaros. ${ }^{22}$

There are obvious parallels between how the royal families of Norway and Denmark in the 1160s consciously constructed their legitimacy and tried to consolidate their power by establishing an alliance with the Church by creating a triangle of royal saint, mausoleum, and anointment and coronation. This was not necessarily a direct reflection of the practise in the Latin kingdom of Jerusalem, but a close parallel, as most of the Latin kings were crowned and buried in the Holy Sepulchre Church, underlining their status as servants and vassals of Christ. ${ }^{23}$

\section{The Cult of St Olav at the New Metropolitan See of Nidaros}

In July 1152, Cardinal Nicholas Brekespear (c.1100-1159) arrived in Norway with the papal mandate to establish two new archbishoprics in Norway and Sweden respectively. The cardinal made his way north to Nidaros, and during the winter of 1152/1153 the archbishopric of Nidaros was formally established as the second Nordic archbishopric after Danish Lund (1104). Bishop Jon of Stavanger was elected as the first archbishop, invested with the pallium the cardinal had brought from Rome.

Leaving Norway, Cardinal Nicholas traveled to Sweden in order to establish a third Nordic archbishopric consisting of Sweden and Finland, but his succesful visit to Norway stands in contrast to the situation he met in Sweden. The various Swedish factions were unable to agree on the location of the metropolitan seat, and the cardinal had to leave Sweden without completing his task. He left the pallium in the care of the archbishop of Lund with a mandate to invest the first archbishop.

22 Jens Fleischer, “Danske kongegrave i et europæisk perspektiv,” in Danske kongegrave, ed. Karin Kryger (Copenhagen: Museum Tusculaneum Forlag, 2014), 28.

23 Denys Pringle, The Churches of the Crusader Kingdom of Jerusalem. A Corpus. Volume III: The Kingdom of Jerusalem (Cambridge: Cambridge University Press, 2007), 16. 
In spite of this setback, Cardinal Nicholas' expedition was still judged successful enough to elect him pope shortly after his return to Rome, under the name of Hadrian IV. ${ }^{24}$ It took another eleven years before Sweden finally received its own archbishop with Old Uppsala as the metropolitan seat. One important reason for this was the lack of a strong and stable monarchy in Sweden that could play a decisive role in the process.

Another difference between the two countries was that Sweden lacked the relics of a major saint which helped to create an undisputed religious centre in the country in the way that Nidaros already had been for more than a century in Norway. Ironically, one of the two kings who ruled Sweden during the cardinal's visit, Erik Jevardsson (c.1120-1160) was to become this saint a few years later. As a result, the construction of a large new metropolitan cathedral on the new location of Östra Aros (today Uppsala) began only in the 1270s, when Nidaros Cathedral was in the final stages of its completion. Östra Aros was the site of the martyrdom of King Erik in 1160, whose shrine became the focal point of the new cathedral. The new cathedral of Uppsala was not placed on the actual site of Erik's martyrdom, but some $50 \mathrm{~m}$ further north. A smaller chapel dedicated to the saint was built on the presumed site of his martyrdom. ${ }^{25}$

However, the cult of St Erik took a long time to spread outside the Svealand region surrounding Uppsala and Stockholm. A conflict between the chapters of Uppsala and Nidaros in the 1340s demonstrates this. For centuries, the inhabitants of North Sweden (Norrland) had voluntarily paid a special tax to St Olav and the Nidaros Cathedral, but now the Uppsala chapter wanted this tax directed to their cathedral which was in need of building funds. But the population of this province was unwilling to desert St Olav and naturally, the Nidaros chapter protested vehemently. The matter went all the way to the papal curia. To strengthen their argument and win over the stubborn northerners, the Uppsala chapter established a new altar dedicated to St Olav and a large statue of the saint was placed in the north portal of the nave, facing the northern regions. Eventually, it seems that the Uppsala chapter emerged victorius from this strife. ${ }^{26}$

24 Erik Gunnes, Erkebiskop Øystein - Statsmann og kirkebygger (Oslo: Aschehoug, 1996), 64. 25 Ronnie Carlsson, “Sankt Eriks kapell,” in Sveriges kirker, ed. Christian Lovén (Uppsala: Kungl. Vitterhets Historie och Antikvitetsakademien och Riksantikvarieämbetet, 2010), 379-383. For medieval interpretations of this site and its significance, see Chapter 24 (Biörn Tjällén), 520-33.

26 Ingrid Lundegårdh, "Kampen om den norrländske Olavskulten," in Helgonet i Nidaros. Olavskult och kristnande i Norden, ed. Lars Rumar (Stockholm: Risarkivet, 1997), 129. 


\section{The Archbishopric and the Cult of St Olav}

As a part of the Nidaros celebrations in 1153, the Icelandic priest and poet Einarr Skúlason (c.1100-after 1159) was commissioned to create a large poem of 71 verses describing the life and miracles of St Olav. Einarr recited his poem in Christchurch Cathedral in the presence of the three kings who were sharing the throne at the time. When the recital ended, the cathedral was filled with a wonderful scent - a sign that the saint was present and approved of the poem. ${ }^{27}$

Einarr called his poem Geisli, which translates as "sunbeam" or "ray of light," thus indicating one important theme in the St Olav cult: his similarity with Christ and the parallels between their passions and miracles. Both Christ and St Olav healed the blind, mute and lame, and the sun is said to have eclipsed when they both died. Einarr also described other miracles taking place right up to his own time, and he dwelt especially on St Olav appearing in the battle between the Byzantines and the invading Turkish Pechenegs during the reign of Emperor Alexios I Komnenos (r. 1081-1118). This happened probably in 1091, when the Scandinavian or Varangian Imperial Guard saved the Byzantines in the battle with the Pechenegs. After this victory, a church dedicated to St Olav was built in Constantinople in gratitude for his assistance, and precious gifts were sent to Nidaros Cathedral. ${ }^{28}$

Geisli marks a transition point in the cult of St Olav, giving the first indications of a comprehensive cult with a clear aim. The further development of the cult was undoubtedly the brainchild of the second archbishop, Eystein Erlendsson (c.1120-1188), who was the chancellor [fehirde] of King Inge, and appointed archbishop in 1157. After traveling to Rome to receive his pallium, Eystein reigned until his death 30 years later in January $1188 .^{29}$ Until 1180, when Sverre Sigurdsson, the new pretender to the throne, gained the upper hand and Archbishop Eystein went into exile for three years, the archbishop enjoyed free hands to build and develop the cult of St Olav. In addition, Archbishop Eystein also performed the first coronation in Scandinavia in Bergen in 1164, placing all his prestige behind the new childking Magnus Erlingsson (r.1156-1184) and his father Erling Ormsson skakki ("Wryneck", d. 1179) in exchange for wide-ranging economic and legal privileges for the new archdiocese. ${ }^{30}$

During Archbishop Eystein's reign, the permanent framework of the cult of St Olav was created. The liturgy - liber ordinarius - and the music - officio - were partly

27 Knut Ødegård, “Geisli, det guddomelege ljoset,” in Geisli. Gjendikting ved Knut Ødegård (Trondheim: Tapir Akademisk Forlag, 2003), 22.

28 Passio Olavi, 23.

29 The saga tells that he was appointed by the king right after the death of Archbishop Jon in 1157. The inscription states, however, that the chapel was dedicated on 26 November 1161, in the first year of his episcopacy.

30 For the political manoeuvres of Erling Ormsson, see Chapter 6 (Pål Berg Svenungsen), 96-112. 
compiled from older versions and partly newly written to fit the spesial circumstances of the new archbishopric, compiled in the Ordo Nidrosiensis. ${ }^{31}$ The Office of St Olav contains the famous sequence Lux illuxit laetabunda which uses the same symbolism as the poem Geisli, i.e. comparing St Olav with the divine light streaming over the world, which is a metaphor used for Christ.

During the 1160s and 1170s, the miracles and a short hagiography of St Olav were also collected and partly written by Archbishop Eystein, who himself narrated some of the miracles and was the object of one of them. This collection is today known as the Passio et miracula beati Olavi. ${ }^{32}$ To aid the clergy in dealing with local situations not covered by the Canon Law, the archbishop also compiled the Canones Nidrosienses, consisting of a large number of questions sent to the pope and the pope's answers to them. ${ }^{33}$

Archbishop Eystein also introduced a new Church Law for the province. ${ }^{34}$ In connection with the coronation of the young King Magnus, Archbishop Eystein introduced a new Law of Royal Succession and the concept of St Olav as the eternal king of Norway [rex perpetuus Norvegie]. The earthly king received his crown as a vassal of St Olav, and swore that after his death, his crown should be sacrificed to Nidaros Cathedral. ${ }^{35}$ This act of sacrificing the royal crown as a symbol of vassalage was a new tradition that originated in the crusader kingdom of Jerusalem, where the kings were vassals of Christ. ${ }^{36}$

\section{Archbishop Eystein as Augustinus}

Altare hoc dedicatum est ab Augustino archiepiscopo ... begins the long dedication inscription in the Chapel of St John the Baptist, dedicated on 26 November 1161. Writing in Latin, Archbishop Eystein used the name Augustinus, which was a

31 Agnar Sandvik, "Messe- og tidesang i den norske middelalderkirken," in Nidaros erkebispestol og bispesete 1153-1953, ed. Arne Fjellbu (Oslo: Forlaget Land og Kirke, 1955), 635-58; Gisela Attinger and Andreas Haug, eds., The Nidaros Office of the Holy Blood. Liturgical Music in Medieval Norway, Senter for middelalderstudier, skrifter nr. 16 (Trondheim: Tapir Academic Press, 2005); Eyolf Østrem, "The Early Liturgy of St. Olaf," in Gregorian Chant and Medieval Music. Proceedings from The Nordic Festival and Conference of Gregorian Chant Trondheim, St. Olaf's Wake 1997, ed. Audun Dybdahl, et al., Senter for middelalderstudier (Trondheim: Tapir Academic Press, 1998), 43-59.

32 Frederick Metcalfe, Passio et Miracula Beati Olavi (Oxford: The Clarendon Press, 1881); Passio Olavi.

33 Gunnes, Erkebiskop Øystein, 135-9.

34 Two such laws are mentioned in the sources, named Grágás (Grey Goose) and Gullfjær (Gold Feather) after the codexes containing these laws. See Gunnes, Erkebiskop Øystein, 131-3.

35 Gunnes, Erkebiskop Øystein, 122-8.

36 Trond Norén Isaksen, Hellig krig om Norges krone (Oslo: Forlaget historie \& kultur, 2017). 
conscious choice on his part, as it is not a translation of his Norse name. The reason is obvious: Eystein was was himself an Augustinian, probably educated at the Abbey of St Victor in Paris - as were his two immediate successors. ${ }^{37}$ During Eystein's reign, six Augustinian houses were founded in Norway, at least two of them by Eystein himself. One was the priory of Sancta sedes across the river from the cathedral of Nidaros, where the archbishop was the titular abbot.

During the twelfth century, the Augustinians formed an intellectual elite of Western Europe, and the Abbey of St Victor was the greatest centre of learning. The teachers of the abbey had a strong interest in Ezekiel's prophesy of the Heavenly Jerusalem and contemporaneously developed a close connection to Crusader Jerusalem. All the main religious sites in Jerusalem, like the Church of the Holy Sepulchre, the Templum Domini on the Temple Mount, St Mary's Church on Mount Sion, and the Ascension Church on the Mount of Olives had Augustinian houses attached, which gave the Augustinians enormous power and influence over the holy sites. ${ }^{38}$

Through the movement of the canons between the various abbeys, the network of the Augustinian Order must have played a vital role for the transmission of ideological conceptions of Jerusalem to the west. The Abbey of St Victor was the hub of this movement, and the later archbishops of Nidaros must have received important impulses and inspiration during their stay in the abbey. ${ }^{39}$

\section{Nidaros as a Pilgrim Town}

When studied in a historical context, one can see that by 1200 not only the cathedral, but the whole town of Nidaros and its nearest environs was transformed into a liturgical landscape which would have been easily recognizable to pilgrims and travellers coming from afar. The parallels with other places of pilgrimage are striking. The leading clerics of Nidaros clearly had a vision of how they wanted to develop the town on par with other places of pilgrimage, and Jerusalem was the ultimate model for a pilgrim town in the twelfth century.

When approaching the town by road from the south, the location on the hill of Byåsen where the travelers got their first glimpse of the cathedral and the town, was in 1179 called Feginsbrekka, a Norse translation of the Latin Mons Gaudi (Mount Joy). ${ }^{40}$ The fact that this Latin name was translated into Norse shows that the knowledge

37 Gunnes, Erkebiskop Øystein, 49.

38 Ekroll, "Olavsrelikvier," 326-328.

39 It is unknown if any of them ever visited the Holy Land, or whether any Augustinians who had lived in the Holy Land ever came to Nidaros.

40 For further discussion of this and other similar locations, see Chapter 10 (Anthony Bale), 191-7. 
about this kind of pilgrimage place was established not just among the clergy, but also among the laypeople. This location was probably marked, perhaps by a cross.

Further on along the hill, the road passed under the walls of the royal castle of Sverresborg or Zion from c.1180, situated on a large rocky outcrop. From the road, the town was not yet visible, but from the keep of the castle the king's men could observe the town and all the ships arriving and leaving its busy river harbour. A few minutes later, the pilgrims stood on the brink of the steep hill of Steinberget, offering a wonderful view of the whole town situated on the flat peninsula below the hill, strung out along the lower stretch of the river Nid.

During the twelfth century, the town had grown quickly. In adddition to the large royal and archiepiscopal building projects, 10-12 smaller parish or guild churches were built. The many whitewashed stone churches but especially the cathedral rose above the low wooden houses with their green turf roofs, and the town was surrounded by three monasteries: towards the north the Benedictine Abbey of St Lawrence at Munkholmen island, towards the east St Mary's nunnery at Bakke east of the river and to the south the Augustinian priory Sancta Sedes south of the river. These three monasteries with their inhabitants living in prayer formed a spiritual ring of defense around the town. Towards the west, a protective castle wall of earth and wood was built across the narrow neck of the peninsula, and only after passing through its gate, the traveller could enter the town, even though the western half of the peninsula still consisted of open fields with a few houses.

The traveler's gaze must invariably have been drawn towards the large complex of stone buildings in the riverbend on the south side of the town, their height and size signaling that here lived the high and mighty. In the middle of this complex, on the highest point of the peninsula, rose a church far larger than the rest, even if the jagged walls and lack of roofs showed that some of it was still clearly under construction. This was the destination of the long walk, the cathedral which was the resting-place of the saint (Fig. 14.2).

Walking towards the cathedral precinct, a traveller would see many things that were instantly recognizable. The precinct was surrounded by a wall with gates, providing some extra security. On the south side of the cathedral rose the impressive stone walls of the archbishop's residence, while on the north side a cluster of large houses and halls designated the location of the canons' residences. East of the cathedral, between it and the river, the halls and towers of the king's residence were visible. To the south, a very long wooden bridge provided an easy passage across the river not just for travelers from the east, but also for farmers bringing their produce to the town and for the workers and animals transporting stone on sleighs from the quarries east of the town for the ever-expanding cathedral. On the north side of the cathedral, a cluster of isolated buildings marked the location of St Mary's hospital for exhausted or sick pilgrims.

Arriving by sea, the ship would enter the town's harbour situated in the lower part of the river. A large cross was raised on the point where the River Nid joined 


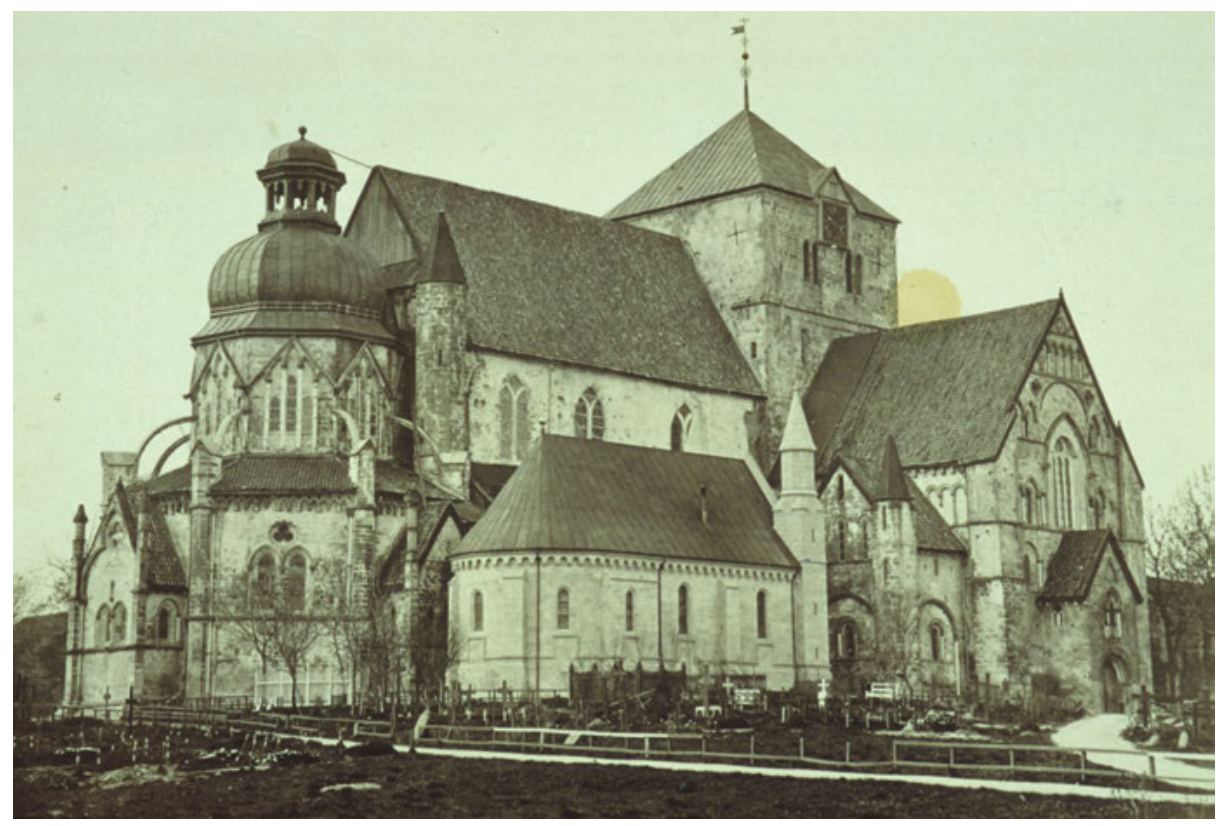

Fig. 14.2: Nidaros Cathedral, seen from the NE in 1872. The chapter house is restored, and the restoration of the octagon (to the left) is yet to begin. The Baroque cupola with its open lantern was soon after replaced by the present pointed spire, which is a reconstruction of the medieval roof.

the fjord, signalling that this was a Christian town. A tall watchtower of stone protected the river harbour against enemies, and behind it lay the compact wooden town with its narrow streets and passages and the market place.

All in all, except some differences in building materials, everything would have been easily and comfortingly recognizable to all pilgrims who had visited other cathedral towns on his or her way north. It must have felt very reassuring to arrive here to relative safety and comfort, after the long weeks spent walking though often terrifying and unpopulated mountains and narrow valleys or sailing along the rocky coast to reach their destination.

\section{The Zion of the North}

The castle Zion or Sverresborg was built by King Sverre Sigurdsson (1151-1202), who in 1177 emerged from the deep forests near Sweden with a band of ragged brigands in birch-bark shoes, claiming to be the illegitimate son of King Sigurd Munn 
(r.1136-1155)..$^{41}$ Two years later, he won his first great victory: he slew Earl Erling Ormsson skakki in a battle by the cathedral in Nidaros, causing King Magnus to flee to Denmark and Archbishop Eystein to England. To consolidate his newly acquired power, Sverre hurriedly built his castle on the rock. By naming his castle Zion like King David's castle just outside Jerusalem, King Sverre consciously alluded to the Jerusalem model, thus projecting the conflict between Saul and David, two Old Testament monarchs, directly into the contemporary political situation in Norway.

Sverre consciously cast himself in the role of King David, who received a heavenly mandate to rebel against a false king (Saul) and the prophet (Samuel) who had appointed and anointed Saul. This was a very intentionally drawn parallel with Sverre's own struggle with King Magnus Erlingsson and Archbishop Eystein Erlendsson, who had replaced the old law of royal succession in order to have Magnus recognized as a lawful king. ${ }^{42}$ King Magnus was cast in the role of King Saul who had forfeited his kingdom because he had lost his royal legitimacy, even if he was anointed by the Prophet Samuel, i.e. Archbishop Eystein, who was then cast as the wrongdoer who had anointed the wrong man.

Sverre also claimed that as a youth, St Olav had appeared in a dream and given him his own sword and battle standard, i.e. making him his heir. ${ }^{43}$ In 1177 , Sverre had another dream of an old man, who was the prophet Samuel, claiming to be sent by God. In the dream Samuel anointed Sverre's hands with holy chrism which gave Sverre a divine mandate of kingship. ${ }^{44}$

The most important conclusion we can draw from this is that the Holy City of Jerusalem was a highly relevant model for twelfth-century Nidaros, in its urban development, legitimation of political power, and in the developing cult of St Olav. This is supported by the conscious drawing of parallels between St Olav and Christ, in liturgy as well as architecture.

\section{The Second Shrine of St Olav}

With the great expansion of his cult, the old shrine of St Olav, which consisted of his plain wooden coffin covered with decorated sheets of gilt silver, was not deemed

41 King Sigurd was killed in 1155, aged 22. According to the Saga of King Sverre, partly dictated by the king himself, Sverre grew up on the Faroe Islands and became a priest before claiming the throne. The birch-bark shoes gave his men the unflattering name birkebeiner (birch-legs), by which they are still known.

42 According to the old law, all sons of a king were lawful heirs to the kingship, be they legitimate or not. The new law stated that a king first and foremost had to be born in wedlock.

43 The Saga of King Sverri of Norway, ed. and trans. J. Sephton, London: David Nutt, 1899, Sverris Saga.

44 The Saga of King Sverri, ch. 10, Sverris Saga. 
sufficient enough. It was probably in the 1160 s or 1170 s that a second shrine containing the first shrine was made. Snorri Sturluson became well aquainted with this shrine during his stay in Nidaros in the winter 1219/1220 as the guest of Earl Skule Baardsson (1189-1240). Writing Heimskringla ten years later, Snorri included a description of this shrine in the saga of King Magnus the Good, to whom he attributed it:

King Magnús had a shrine made and ornamented with gold and silver and set with precious stones. And this shrine was both in size and its shape made in other respects like a coffin, except that there were legs underneath and ontop the lid was shaped like a roof and up above it figureheads and a ridge. On the lid there are hinges at the back and hasps in front, and these are locked with a key. ${ }^{45}$

This description fits exactly with the design of a group of small reliquaries in Iceland, Norway, and Northern Sweden which clearly were made as copies of St Olav's second shrine. ${ }^{46}$

However, Snorri's dating of the church-shaped shrine must be incorrect. Shrines of this size do not belong to the mid-eleventh century but to the late twelfth or the thirteenth century. It is more likely that it was the oldest coffin from 1030 that King Magnus the Good covered with sheets of gilt silver. But then, who commissioned the second shrine, and why was Snorri told by the cathedral clergy that it was donated by King Magnus the Good (r. 1035-1047)? I believe that this was a white lie or pia fraus, and that it was another King Magnus - Magnus V Erlingsson - who donated the shrine some time between 1164 and 1184 as an act of gratitude for the archbishop's support.

There were also other Jerusalem relics in the cathedral. In 1110, King Sigurd Magnusson the Crusader obtained a piece of the True Cross for the cathedral in Jerusalem from King Baldwin. ${ }^{47}$ In 1165, a golden ring containing some drops of the Holy Blood arrived in Nidaros, a costly gift best understood as a gift of gratitude after the coronation of Magnus in Bergen the year before. ${ }^{48}$ After Magnus was killed and King Sverre founded a new dynasty, the cathedral clergy seems to have adapted to the new political situation by conveniently forgetting the recent King Magnus $\mathrm{V}$ and instead attribute the great shrine to St Olav's own son Magnus I, who was also buried in the cathedral.

45 Snorri Sturlusson, Heimskringla, vol. 3, Magnúss saga ins goða, ch. 10.

46 Øystein Ekroll, "St. Olavs skrin i Nidaros,” in Ecclesia Nidrosiensis 1153-1537. Søkelys på Nidaroskirken og Nidarosprovinsens historie, ed. Steinar Imsen, Senter for Middelalderstudier, NTNU, Skrifter, Bd. 15 (Trondheim: 2003), 328.

47 Snorri Sturlusson, Heimskringla, vol. 3, Magnússona saga, ch. 11. For this cross relic and its long and complicated way to Nidaros, see Chapter 8 (Lukas Raupp), 156-65.

48 Islandske Annaler indtil 1578, ed. Gustav Storm, Christiania: Grøndahl \& Søns Bogtrykkeri, 1888. 
In several European countries, the 1160s and 1170s were important for the creation of new shrines for royal saints. During these two decades, a group of new royal saints were created, most of whom needed shrines. Most or perhaps all of these shrines were house-shaped, and a new and more splendid shrine for St Olav would fit well into this development. ${ }^{49}$

According to independent descriptions from the Reformation period, there were then three shrines, one standing inside the other, "but the outer one had no bottom." This was in fact a protective "cover" which had to be hoisted up by the help of ropes and pulleys and is a parallell to important English shrines like St Cuthbert's in Durham, St Edmund's in Bury or St Thomas Becket's in Canterbury. ${ }^{50}$

\section{Stiklestad, a Golgotha of the North?}

Nidaros was not the only place of pilgrimage associated with St Olav. His site of martyrdom at Stiklestad clearly played a vital role in his cult, even if the written sources are sparse. The Passio et miracula beati Olavi tells that a stone church was built on the site, and the boulder or stone on which the king leaned when he was killed was incorporated in the altar so that it was partly visible, complete with blood stains from the saint. ${ }^{51}$ The dedication of the church, which is still standing at Stiklestad, must have taken place in the early 1160s, as its chancel is strikingly similar to the Chapel of St John the Baptist from 1161 in the Nidaros cathedral. In the twelfth century, two or more crosses stood on the battlefield, probably marking important locations. ${ }^{52}$ In the sixteenth century we hear that the supposed barn or shed where the king's body was hidden was still standing, and the king's blood was still visible on its walls. ${ }^{53}$

The Passio Olavi describes three miracles that took place in the church which was built on this site. When the church was dedicated, a king staying at the royal manor of Haug, not far from the church, had a life-threateningly infection in his leg. His servants carried him to the church and placed his leg against the stone on which St Olav

49 Among these new shrines for royal saints could be mentioned King Erik of Sweden (1160), King Edward the Confessor of England (1163), the Magi, venerated as kings (1164), Charlemagne (1165), and the two Knuds of Denmark, the king and the duke (1170). See Chapter 5 (Øystein Ekroll), 92.

50 Ekroll, "St. Olavs skrin i Nidaros," 331-4.

51 Passio Olavi, 47.

52 The standing monument from 1807 replaced an older monument in a tradition going back to the Middle Ages. A hillock close to it is called Korshaugen (Cross Hill), indicating the existence of a cross here once, and below it runs Korsbekken (Cross Brook).

53 Historisk-topografiske Skrifter om Norge og norske Landsdele forfattede i Norge i det 16de Aarhundrede, ed. Gustav Storm, Christiania: A.W. Brøggers Bogtrykkeri, 1895. 
once had died, and he was immediately cured.$^{54}$ In the second miracle a blind woman regained her eyesight in the church, and in the third, a deaf and mute young man was cured when he fell asleep in the church and St Olav appeared before him in a dream. ${ }^{55}$

Regardless of the historical truth in these stories, during the Middle Ages Stiklestad was a location where the last day of St Olav's life could be experienced and relived by pilgrims who would even touch the famous stone. With the crosses on the hillocks, the blood-dyed stone and the small shed resembling a burial chamber, the site seemed to be developed in a way which echoed the lay-out of Golgotha. Stiklestad would also be a natural stop for pilgrims heading from Nidaros from the east and the north.

\section{Jerusalem in Nidaros Cathedral}

The importance of St Olav's grave for the development of Nidaros Cathedral can hardly be overstated. In 1887, the sharp-minded state antiquarian Nicolay Nicolaysen correctly stated that "the grave is the red thread running through the history of the cathedral." ${ }^{\text {}}$ For nine centuries, the high altar has been the fixed and stable point in a cathedral which has lived through numerous alterations. The large building campaigns undertaken on the cathedral during the Middle Ages can only be understood in the context of its multiple roles as a pilgrimage church, a metropolitan church with a large chapter of canons, a royal and aristocratic burial church, a coronation church, and the cathedral of the Nidaros diocese.

Very few major Christian churches combine the grave and the shrine of the saint. The vast majority of relics of saints were transferred to other sites and churches, and the bodies or bones of most saints were also divided up and scattered across large areas. It is remarkable that so much effort was put into presenting the high altar of the Christchurch as standing on the very grave site of St Olav, when he was in reality buried on the riverbank $c .200 \mathrm{~m}$ to the south.

According to a late medieval saga, shortly after Olav's canonization a wooden chapel was built over this grave on the riverbank. ${ }^{57}$ Building a chapel over the site of martyrdom or the grave is a parallel to other royal saints, e.g. St Knud Lavard in Denmark, St Edmund in England and St Erik in Sweden. But in Nidaros we hear

54 Passio Olavi, 47. A stone which was found under the floor during the church's restoration in 1928-1929, and which some believe was the stone described in the saga, has recently been inserted in a niche in the back of the altar.

55 Passio Olavi, 48, 74.

56 Nicolay Nicolaysen, “Atter om Throndhjems domkirke,” Historisk Tidsskrift 2. rk., no. 6. bd. (1887): 44.

57 Johan Hadorph, S. Oluffz Saga paa Swenske Rijm, Stockholm, 1675. 
nothing more about this chapel. Instead, the gravesite and the shrine became combined at the high altar in the cathedral.

It is very possible that the "transferral" of the gravesite from the riverbank to the cathedral took place only in the late twelfth century when the octagon was under construction, in order to underline its close resemblance to the Holy Sepulchre Church in Jerusalem. After all, the first mention of this connection is found in Snorri's Heimskringla from c.1230, and by then this was clearly an established "truth" on par with the story of who donated the second shrine of St Olav. If so, it underlines the conscious effort of linking St Olav to Christ by presenting the grave and the shrine on the same spot and in the same building, and suppressing the possible original location of St Olav's grave. ${ }^{58}$

The greatest attraction of St Olav was the claim that his body was preserved in an incorrupt state. At the time of the Reformation, various sources attest that a complete body lay in the shrine, but later historians have suggested that this was not the real St Olav, but a later replacement after the original body was cut up for relics. ${ }^{59}$ Interestingly, not a single known medieval source mentions an undisputed body relic of St Olav, only brandea (secondary or contact relics). Most of these relics consist of pieces of his shirt or standard, both of which were handily preserved as relics in the Nidaros Cathedral. ${ }^{60}$ In order to experience the body relics and the spiritual power of St Olav one therefore had to venture to Nidaros Cathedral and pray at the shrine containing his incorrupt body, a powerful argument in favour of undertaking a hazardous pilgrimage to the northernmost shrine in Christendom.

Among the most important churches combining grave and altar/shrine are of course the Holy Sepulchre Church in Jerusalem, and Canterbury Cathedral in England, where the shrine of St Thomas Becket stood since the 1180s in the feretory built directly over the site of his temporary grave in the old crypt below. In Rome, the graves of the apostles Peter and Paul are still preserved under the high altars of the Basilica di San Pietro in the Vatican and in San Paolo fuori le Mura. In contrast, St Erik of Sweden and St Knud the King of Denmark were enshrined in a different church a short distance from their site of martyrdom.

58 When the site of the high altar was excavated in 1872, two altar foundations were found. According to the excavator, the older and smaller foundation belonged to the eleventh-century chancel, while the upper was contemporary with the octagon. It measured $4.2 \times 4.2 \mathrm{~m}$, which indicates that it could have supported some kind of edicule or symbolic burial chamber as well as the altar and shrine base. See Krefting, "Supplement til en i 1865 i Throndhjems Domkirke foretagen Undersøgelse".

59 Grethe Authén Blom, Helgenkonge og helgenkrin. En kongeskikkelse i forvandling fra sagatid til reformasjonstid, Småskriftserien (Trondheim: Nidaros Domkirkes Restaureringsarbeiders forlag, 1994), 23.

60 Ekroll, “Olavsrelikvier,” 266-72. A silver reliquary contained the shirts (NB! plural) of St Olav. 


\section{The New Cathedral}

The establishment of the new archbishopric in 1153 unleashed a cultural activity and creativity in Nidaros during the next 30-40 years which was never surpassed. Before 1200, the old Christchurch had been greatly expanded into a cross-shaped Romanesque cathedral in which the old Christchurch was retained as the east arm.

An unusual feature of the cathedral is that it contains double chapels. The north and south transepts have floor-level chapels protruding towards the east, but there are also upper chapels on the triforium level above them. In the south transept, the altar of the lower chapel was consecrated by Archbishop Eystein on 26 November 1161, as attested by a carved dedication inscription running around three walls. It was dedicated to St John the Baptist, St Vincent, and St Silvester. The cult of these three saints was encouraged during the Gregorian reform, and connects the archbishop directly to the reform movement. The first two saints stood up againt tyrants and lost their lives for their faith, while Silvester was the pope who it was (falsely) believed to have given the temporal power by Emperor Constantine the Great, which placed the pope above the emperor, sacerdotum above regnum. ${ }^{61}$

The upper chapel, situated above the Chapel of St John the Baptist, demonstrates a direct link to Jerusalem. It was dedicated to St Olav and St Stephen on 5 January. This dedication inscription sadly omits the year, but it cannot be much later than the lower chapel, perhaps in the mid-1160s. The dedication inscription is carved into the east wall of the chapel and states that it was jointly dedicated to SANCTI STEPHANI PROTOMARTYRIS ET SANCTI OLAVI, relics of whom were contained in the altar together with CORPORE DOMINI, i.e. a consecrated host. The inscription explicitly connects the first Christian martyr with the first Norwegian martyr. Interestingly, the translation day of St Olav was 3 August, which was also the feast day for the invention of the relics of St Stephen in Jerusalem. ${ }^{62}$ This created a second connection between the two saints, which was clearly not coincidental. Describing King Olav's death in the battle of Stiklestad, the Historia de antiquitate regum Norvagiensium (History of the ancient Norwegian kings) written c.1180 in Nidaros by Theodricus, also draws a parallel between St Stephen and St Olav. The author underlines how Stephen prayed for those who stoned him and how Olav gave donations to those who later would kill him, as depicted on an altar frontal made in Nidaros around 1300, to which I will return below (Fig. 14.3). ${ }^{63}$

61 Eirik Vandvik, Erkebiskop Eystein som politikar, Utgitt ved 800-årsminnet for vigselen av Johanneskapellet 26. november 1961 (Trondheim: Nidaros Domkirkes Restaureringsarbeider, 1961,) 4-6. 62 I am grateful to Mr. Eirik Steenhoff for pointing this out to me.

63 Theodoricus Monachus, An Account of the Ancient History of the Norwegian Kings, in Text Series 11, trans. David McDougall and Ian McDougall, London: Viking Society for Northern Research, 1998. 


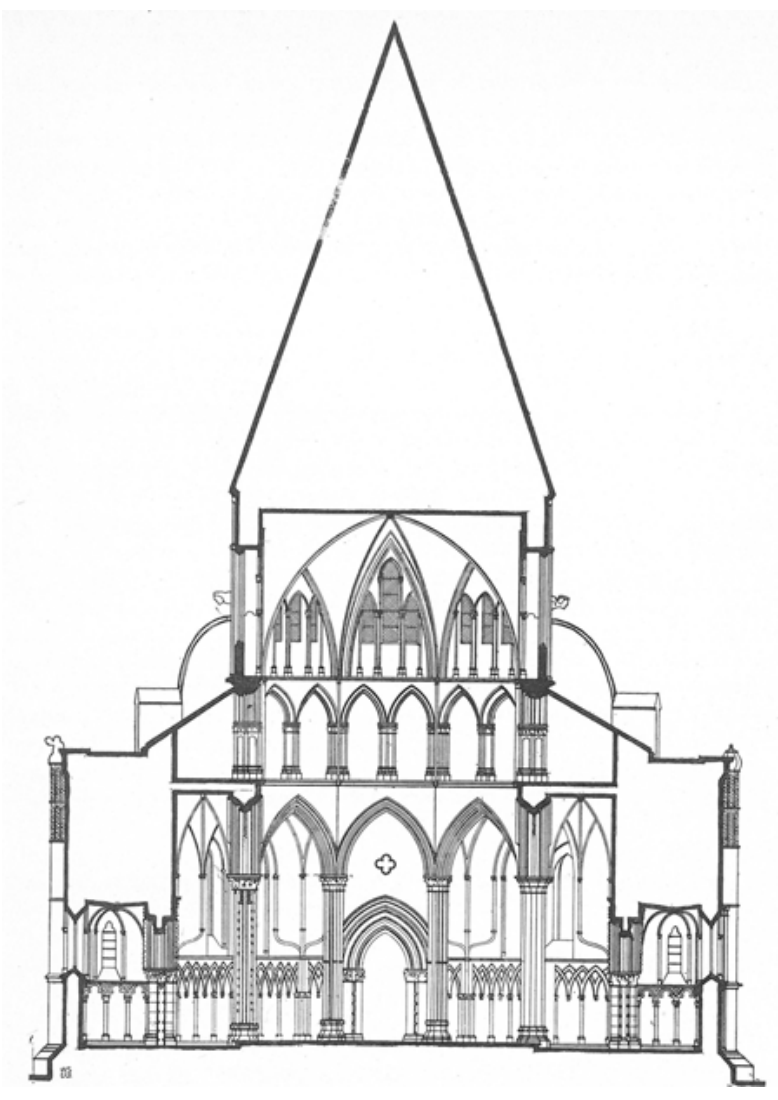

Fig. 14.3: Vertical section of the Nidaros Cathedral octagon seen towards the East. Drawing by Hermann M. Schirmer, printed in Johan Meyer: Domkirken i Trondhjem (Trondhjem 1914), Fig. 10. In this reconstruction drawing, the triforium arches lack their detached shafts and tracery.

\section{Crowning the Work: The Octagon}

A cathedral is a physical construction, but also a spiritual one. Apart from Nidaros, it is doubtful whether any other cathedral in Scandinavia was designed as a place of pilgrimage, or any other cathedral where pilgrimage and the cult of a saint was so crucial for its existence.

In spite of the great rebuilding, architecturally the cathedral c.1200 did not stand out in a special way when compared to other contemporary cathedrals in Europe. The saint's shrine was still kept in the square eleventh-century choir which was cramped and presented many practical problems. The choir had become too narrow for the combination of the saint's growing status, the developing liturgy, the royal tombs, the number of clerics, and the ever-growing number of pilgrims. The emphasis now put on the similarities between St Olav and Christ in liturgy, literature, and iconography also necessitated an architectural expression which could physically visualize this connection. 
There can be no doubt that without the cult of St Olav, Nidaros Cathedral would never have been built as large as it actually was. Most first-time modern visitors express surprise at finding such a large church so far north, and this experience must have been even more striking in the Middle Ages. Nor would the Metropolitan See of Norway have been placed in Nidaros, but rather in Bergen or Oslo which also had important cults of St Sunniva and St Hallvard respectively, if less popular than St Olav's.

The key to its symbolism and architecture is St Olav's double identity as king and martyr (rex et martiris). His martyr status was defined shortly after his death, even if he had fallen in battle fighting to the very end, while a Christian martyr should preferrably receive death passively without resisting. The cult of St Olav gradually moulded the old warrior king and former pagan Viking into the more acceptable form of a humble Christian. His cult was partly modelled on older royal cults like those of St Edmund and St Oswald in England, but the greatest inspiration was clearly the worship of the Passion of Christ as it was developed in Jerusalem after the Crusader conquest of the city in 1099.

Nothing makes the cathedral stand out more from other cathedrals than its eastern termination - the octagon - which has no parallel in Northern Europe. No other saints or shrines in this part of Europe received anything like it around their graves or shrines, and any parallels or models for it must be searched for further away. ${ }^{64}$

With the old single-aisled nave of the Christchurch becoming the new choir of the Romanesque cathedral, there was literally space for constructing a new eastern termination and an appropriate building around the grave and shrine of the royal saint. The dating of the commencement of the work on this impressive building part is disputed. The octagon is built in the shape of an Early Christian martyrion church with a centralized plan: a central room surrounded by an ambulatory. It was often believed that Archbishop Eystein got the inspiration for it during his English exile from 1180 to 1183, and that he started its construction immediately after his return to Nidaros. ${ }^{65}$ The outer walls were probably built then. When completed, the central room of the octagon would have looked not unlike the round nave of the Temple Church in London which was consecrated no later than 1185 , and perhaps already in $1163 .{ }^{66}$ The octagon must have been completed no later than $c .1210 / 1215$.

\footnotetext{
64 For a comprehensive study and analysis of the octagon, see my PhD thesis from 2015 (Øystein Ekroll, "The Octagonal Shrine Chapel of St Olav at Nidaros Cathedral: An Investigation of its Fabric, Architecture and International Context” (PhD Thesis, NTNU, 2015)).

65 Gerhard Fischer, Domkirken i Trondheim I-II. Kirkebygget i middelalderen (Oslo: Forlaget Land og Kirke, 1965), 127-34.

66 Christopher Wilson, "Gothic Architecture Transplanted: the Nave of the Temple Church in London," ed. Robert Griffith-Jones and David Park, The Temple Church in London: History, Architecture, Art (Woodbridge: The Boydell Press, 2010), 16-45.
} 
The ambulatory walls have pointed arches and openings which give them an impression of Gothic architecture, but the walls are extremely thick and solid, and a closer study of the details reveals that almost all of the ornaments belong to the Romanesque tradition.

Many of these ornaments derive from Classical architecture in general and Roman funerary architecture in particular, like the astragal, kymation and acanthus borders, laurel leaves, palmettes, dentil borders, and Ionic capitals. Those who designed the ambulatory walls clearly wanted a building which gave the visitor a clear association of a grave church resembling the Early Christian martyrion churches (Fig. 14.3).

\section{The Holy Sepulchre Church and the Nidaros Octagon}

These churches were often octagonal, deriving from the mausoleums of the Late Roman emperors, e.g. Diocletian's mauseoleum in Split in present Croatia from c.300 CE. His successor Emperor Constantine the Great built several splendid churches, both basilicas and centralized churches. The latter design, including rotundas as well as octagons, was used especially for churches built above the graves of martyrs, with the Holy Sepulchre complex in Jerusalem as the most splendid example.

This Holy Sepulchre complex was a combination of three elements: a basilica, an atrium, and a vast rotunda with a raised central room surrounding the Tomb of Christ at its center. Constantine's masons isolated the chamber tomb by carving away the living rock surrounding it, leaving it as a freestanding and (probable) octagonal structure in the center of the rotunda. ${ }^{67}$ Despite later destructions and rebuildings, much of the Constantinian structure of the Rotunda still stands today, including the ambulatory walls.

In my view, the ultimate inspiration for the design of the Nidaros octagon can be traced back to the Holy Sepulchre Church in Jerusalem and its appearance after its restoration by the Western crusaders which was completed c.1150. During this work, the Rotunda received the conical roof which it had until the fire of $1808 .^{68}$ The circular Anastasis was the most prestigious Christian site of pilgrimage in the twelfth century, and together with the octagonal Dome of the Rock, which the crusaders wrongly identified as Solomon's Temple and called Templum Domini, it formed the mental background for the construction of the Nidaros octagon which can be regarded as an amalgamation of these two buildings. ${ }^{69}$

67 Virgilio C. Corbo, Il Santo Sepolcro di Gerusalemme I-III (Jerusalem: Franciscan Printing Press, 1982); Martin Biddle, The Tomb of Christ (Stroud: Sutton Publishing, 1982).

68 Pringle, The Churches of the Crusader Kingdom of Jerusalem, $20 \mathrm{f}$.

69 Ekroll, "The Octagonal Shrine Chapel of St Olav at Nidaros Cathedral," 354-8. 


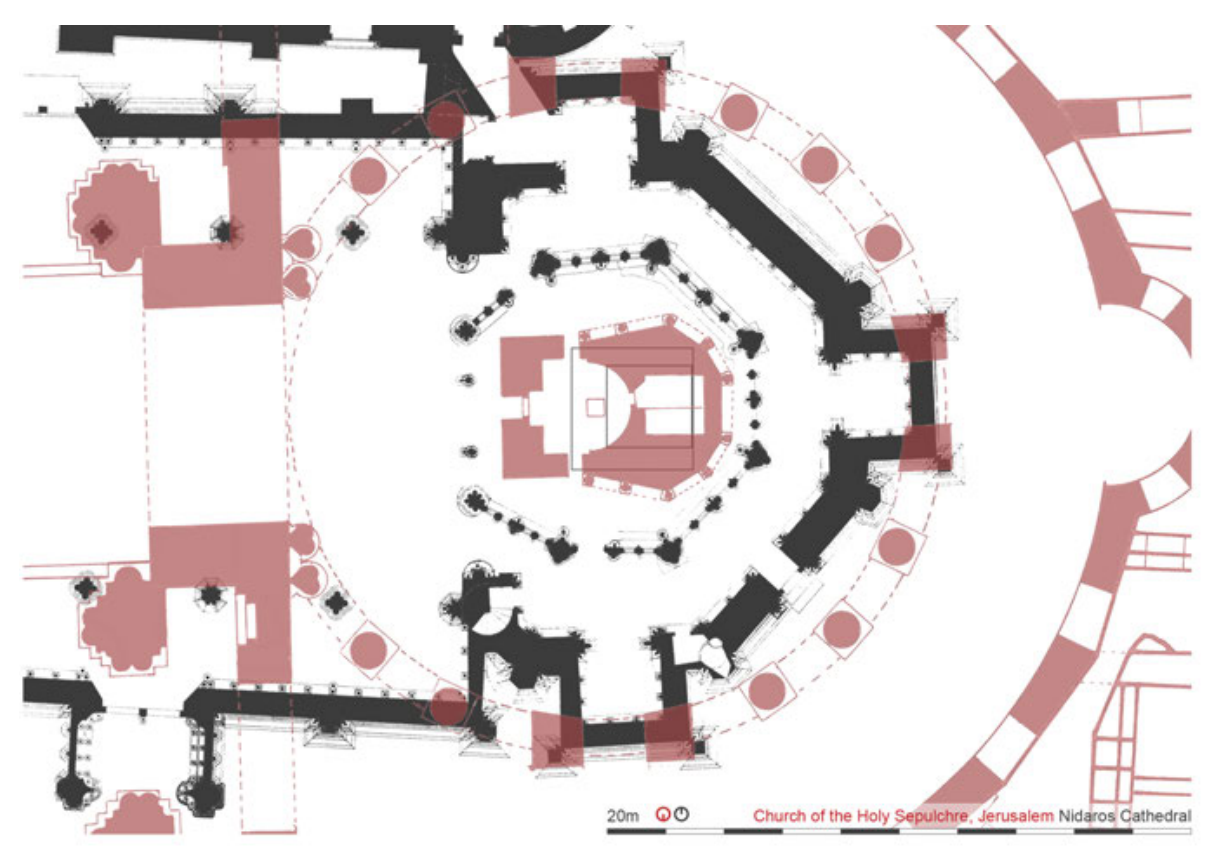

Fig. 14.4: The ground plan of the Holy Sepulchre Church rotunda (in red) interpolated on the plan of the Nidaros Cathedral octagon (in black). Note that the external diameter of the Nidaros ambulatory at ground level seems to be identical to the internal diameter of the HSC rotunda, and the slightly off-centre position of the altar above the gravesite of St Olav coincides with the similar position of the Tomb of Christ. Graphics by Samuel B. Feragen.

Even a superficial look makes clear the similarities in design between the rotunda and the Nidaros octagon c.1200, including the conical roof. But was this only a superficial similarity or can we find a deeper connection? By comparing the ground plans of both buildings, a very interesting picture emerges, especially when interpolating the plans in the same scale: the external diameter of the octagon at ground level is identical to the internal diameter of the arcade surrounding the edicule containing the Tomb of Christ, and the external diameter measured across the octagon chapels, measured at the ground level in the middle of the wall, is identical to the external diameter of this arcade. But the most interesting correlation comes when we interpolate the ground plans of the two buildings. On ground level, the external diameter of the octagon across the chapels is identical with the maximum diameter of the Anastasis arcade, and the outer diameter of the ambulatory is identical with the inner diameter of the Anastasis arcade (Fig. 14.4). This can hardly be a coincidence, and in the Middle Ages the concept of "copy" was different from today: a single feature or a converging measurement was enough for the contemporaries to call one building a copy of another. 
The open space of the central room surrounding the Edicule was the easiest possible measurement to take. It could be measured with a rope, a chain, or a staff, but naturally these measurements were not as exact as moderne measuring methods.

In addition, the position of the altar in the Nidaros octagon, standing on the purported grave site of St Olav, fits exactly with the position of the tomb chamber in the Edicule. Neither of them are located in the center of the building, but are a little off-center so that the centerpoint of the building is occupied by the person performing the liturgy in front of the altar/tomb.

\section{Conclusions and Continuations}

The parallell between St Olav and Christ became even more emphasized in the following centuries. A good example is the well-known St Olav altar frontal which was made in Trondheim $c .1300$ and probably belonged to the Nidaros cathedral (Fig. 14.5). St Olav is depicted in the center, flanked by the symbols of the four evangelists, which is normal for depictions of Christ but highly unusual - probably unique - for a saint. The four scenes, one in each corner, depicting Olav's last days can just as well be read as analogous to the passion of Christ: Olav's dream of the ladder rising to heaven the night before the battle (upper left) relates to Jesus in Getsemane and to Jacob's dream of the angelic ladder. Olav riding to Stiklestad (lower left) alludes to Christ's entry into Jerusalem. Olav's death in battle (lower right) corresponds to Christ's crucifixion at Golgatha, and finally, Olav's translation (upper right) refers to Christ's unction and burial. This Christological analogy must have been approved among the clergy of the cathedral and thus had official sanction. The image of Olav had changed: instead of fighting to the end, Olav was now portrayed as throwing away his weapons and resignedly meeting death like a true Christian martyr should. When he died, the sun was said to turn dark, just like when Jesus died. There was indeed a solar eclipse in this region on 31 August, one month after the battle, and in popular tradition this eclipse was soon fused with the battle. ${ }^{70}$

Contrary to popular belief, the Reformation of 1537 did not spell the end to the interest in St Olav. After being kept safely under lock for almost 30 years in Steinvikholm Castle, his body was brought back to the cathedral in 1564 and placed in an open grave inside the church. This took place during the power vacuum created by the retreat of the Swedish occupying forces. Four years later, however, by royal decree the grave was backfilled and made anonymous.

70 This solar eclipse is mentioned in a poem about St Olav composed by Sigvat, the court scald of King Olav, which is referred to in Snorri Sturlusson, Heimskringla, vol. 2, Óláfs saga helga ch. 227. 


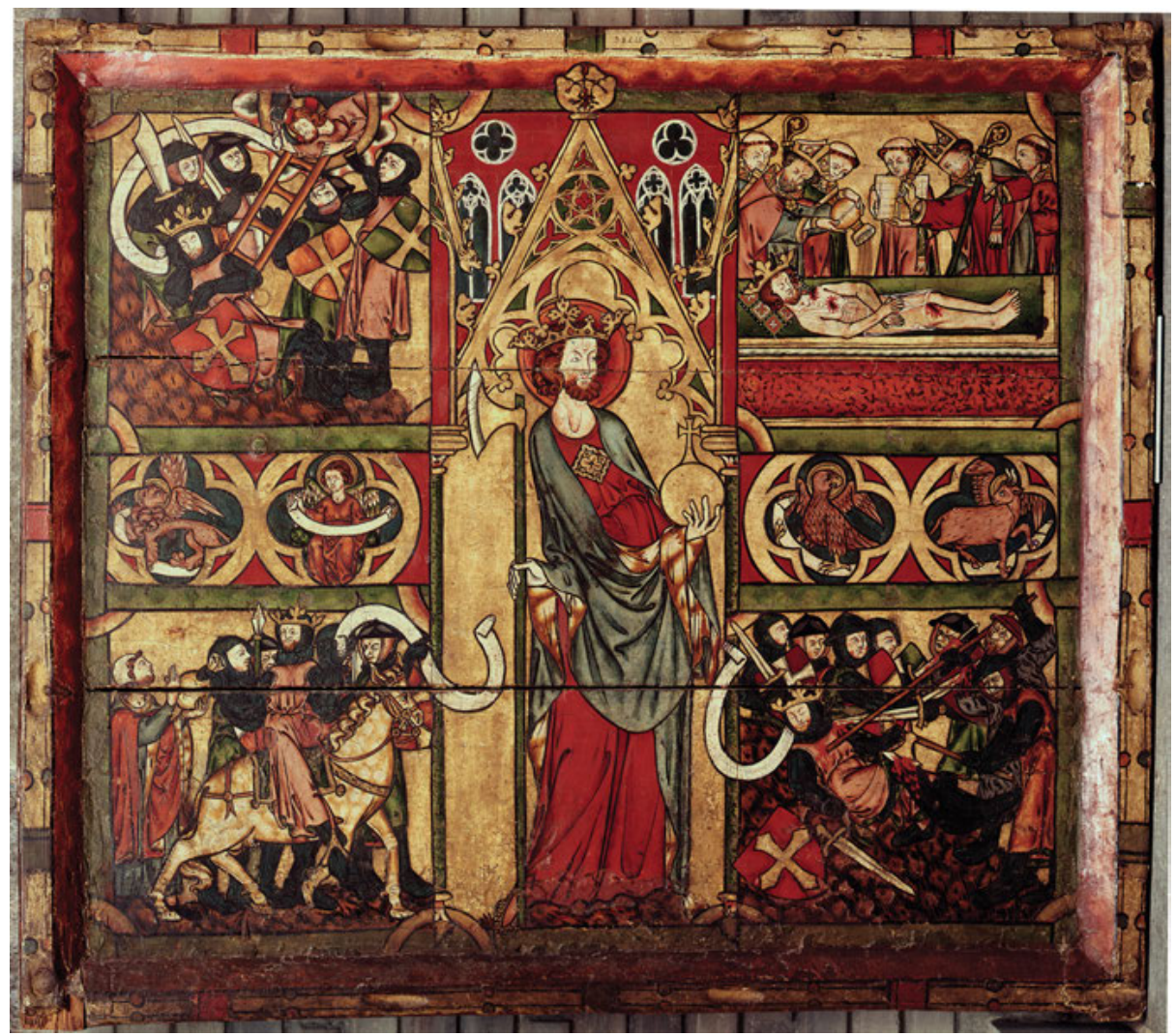

Fig. 14.5: Altar frontal from c. 1300, Trondheim. Nidaros Cathedral. St Olav surrounded by the symbols of the four evangelists and scenes from his passion and death.

In 1611, a curious instance happened which perhaps connects the two St Olav sites of Stiklestad and Nidaros Cathedral. In the cathedral accounts of that year, a sum was paid to a mason for immuring "The Stone of St Olav" in a wall. ${ }^{71}$ The accounts do not tell what this stone was or where it was placed, but in the eighteenth century a large marble stone in the nave wall was identified as this special stone. ${ }^{72}$ The only stone clearly connected with St Olav was the the stone on which he died at Stiklestad. Was this stone brought from Stiklestad Church and united with the saint under the same roof, three generations after the Reformation? When the chancel of Stiklestad Church was restored in 1929, the altar area was excavated but the medieval

71 Trygve Lysaker, Domkirken i Trondheim, Bind III. Fra katedral til sognekirke 1537-1869 (Oslo: Forlaget Land og Kirke, 1973), 20.

72 Ekroll, “Olavsrelikvier,” 259. 
altar had been removed in 1869, when relics of St Ivon and the Holy Men of Selje were found. ${ }^{73}$ Below the altar, there was no trace of any large rock or stone. Had it been brought to Nidaros Cathedral and inserted in the walls of the cathedral ${ }^{74}$

Disregarding the historical value of this scrap of information, it demonstrates that two generations after the body of St Olav disappeared from view, there was still an intense local interest in the saint. During the ensuing centuries, this interest in St Olav turned up in unexpected places. Around 1800 the Trondheim-born governor Ole Bie (1733-1805) of the small Danish-Norwegian colony of Frederiksnagore (Serampore) in Bengal, India, built a new church in the colony and had it named after the saint (and himself). In Trondheim itself, despite conflagrations and urban rebuilding, the historical substance and structure of the medieval city lived and still lives on. The many stories and legends have become an indestructible part of the urban mythos. Most of the places associated with St Olav can still be visited, even if the remains of medieval churches and streets are buried underground. The recent discovery and excavation of what is probably St Clement's Church, with wooden posts dating to $c .1010$, has brought the age of St Olav to light in the middle of modern Trondheim. ${ }^{75}$

73 Per Göte Larsen, Stiklestad kirke. Vårt nasjonale arnested (Verdal: Stiklestad sokneråd, 2013), 47. 74 The diary of Architect Jacob Holmgren, transcribed by Arne Østraat and Øystein Ekroll. The stone which today is placed in a niche behind the altar was salvaged in 1929 by the then minister, and was kept in his family until the 1990s.

75 The excavation of the wooden church was completed in 2018, and the remains and finds are exhibited in a site museum which opened in May 2019. 